\title{
Mekanisme Kerja dan Target Molekuler Interleukin-1 receptor antagonist (Anakinra) pada Aterosklerosis
}

\author{
M. Yulis Hamidy*
}

\begin{abstract}
Inflammation plays an important role in the development and progression of a variety of cardiovascular conditions, most notably coronary atherosclerosis and congestive heart failure. A number of inflammatory molecules have been implicated in these processes, including interleukin-1 (IL-1). IL-1 receptor antagonist is an endogenous inhibitor of IL1 , which competitively binds to the IL-1 type I receptor without activating it. Anakinra is a nonglycosylated, recombinant form of human IL-1ra that, like endogenous IL-1ra, competitively inhibits IL-1 by binding the IL-1 type I receptor.
\end{abstract}

Keywords : interleukin-1, atherosclerosis, receptor

Aterosklerosis merupakan kelainan utama pada penyakit kardiovaskuler. Laporan American Heart Association pada tahun 2010 menyatakan 75\% kematian akibat penyakit kardiovaskuler di Amerika Serikat terjadi karena aterosklerosis. ${ }^{1}$ Aterosklerosis adalah suatu penyakit inflamasi vaskuler yang ditandai dengan akumulasi lipid, kematian sel dan fibrosis pada arteri. Inflamasi ini terjadi melalui interaksi antara lekosit, trombosit dan sel-sel yang terdapat pada dinding pembuluh darah. ${ }^{2}$ Aterosklerosis menyebabkan stenosis pembuluh darah dan apabila mengalami ruptur, plak aterosklerosis dapat mengakibatkan trombosis. Aterosklerosis yang terjadi pada pembuluh darah koroner menyebabkan infark miokard dan gagal jantung, sementara jika terjadi di pembuluh darah otak dapat menyebabkan ischaemic stroke dan transient ischaemic attacks. ${ }^{3}$

Interleukin 1 adalah sitokin yang menginduksi inflamasi dan berperan dalam proses aterosklerosis sehingga dapat dijadikan sebagai target dari obat antiaterosklerosis. ${ }^{2}$ IL-1 $\beta$ memegang peran penting pada proses awal terjadinya inflamasi pada tahap inisiasi aterosklerosis. Sebagai inhibitor dari IL-1 $\beta$ adalah IL-1ra (receptor antagonist).

\footnotetext{
* Penulis untuk korespondensi :

KJF Farmakologi Fakultas Kedokteran Universitas Riau

Jalan Diponegoro No. 1 Pekanbaru, 28111

e-mail: yulis_hamidy@yahoo.com
}

Ketidakseimbangan antara IL-1 $\beta$ dan IL-1ra menyebabkan meningkatnya inflamasi sehingga terjadi aterosklerosis. ${ }^{4}$

\section{PATOGENESIS ATEROSKLEROSIS}

Teori yang saat ini diterima sebagai patogenesis aterosklerosis adalah inflamasi. ${ }^{5}$ Aterosklerosis diawali oleh masuknya low density lipoprotein (LDL) ke bagian dalam dinding arteri, terutama pada segmen dimana terjadi tahanan hemodinamik. Pada dinding arteri yang normal terdapat subendothelial space. Hiperlipidemia dan disfungsi endotel menyebabkan LDL menginfiltrasi dinding arteri melalui subendothelial space tersebut. Selanjutnya LDL mengalami oksidasi menjadi LDL teroksidasi (oxLDL). oxLDL akan mengaktivasi sel endotel. Sel endotel yang teraktivasi mengekspresikan molekul adhesi leukosit seperti Vascular Cell Adhesion Molecule 1 (VCAM-1) pada permukaan pembuluh darah sehingga akan berinteraksi dengan monosit dan limfosit. Monosit dan Sel T berikatan dengan VCAM-1 melalui Very Late Antigen 4 (VLA-4) sebagai respon terhadap kemokin yang dihasilkan sel vaskuler. ${ }^{6}$

Monosit bermigrasi ke dinding arteri melalui endotel yang teraktivasi dan berdiferensiasi menjadi makrofag sebagai respon terhadap MacrophageColony Stimulating Factor (M-CSF) dan stimulus 
lainnya. Selanjutnya terjadi ekspresi berbagai reseptor, seperti scavenger receptor dan toll-like receptors (TLRs) pada makrofag. Scavenger receptor memperantarai pengambilan partikel oxLDL oleh makrofag yang mengakibatkan terbentuknya sel busa. Toll-like receptor akan memperantarai interaksi antara berbagai molekul seperti oxLDL, lipopolisakarida (LPS), endotoksin, Heat Shock Protein (HSP), dan lain-lain dengan makrofag yang selanjutnya menginduksi makrofag untuk mengeluarkan sitokin-sitokin proinflamasi, kemokin, reactive oxygen species (ROS) dan molekul proinflamasi lainnya untuk menyebabkan terjadinya inflamasi di dinding arteri. ${ }^{6}$
Secara skematik proses terjadinya aterosklerosis dapat dilihat pada Gambar 1 di bawah ini. Gambar ini menunjukkan LDL masuk ke dinding arteri dan mengalami oksidasi menjadi oxLDL. oxLDL akan mengaktivasi makrofag untuk mengekspresikan molekul adhesi pada permukaan arteri yang akan berinteraksi dengan monosit. Monosit bermigrasi ke dinding arteri dan berdiferensiasi menjadi makrofag. Pengambilan partikel oxLDL oleh makrofag mengakibatkan terbentuknya sel busa. Sel busa akan mengaktivasi growth factor dan matrix metalloproteinase yang selanjutnya akan menyebabkan sel otot polos vaskuler bermigrasi dan proliferasi dari lapisan media ke lapisan intima arteri. Proses ini akan menyebabkan terjadinya aterosklerosis. ${ }^{7}$

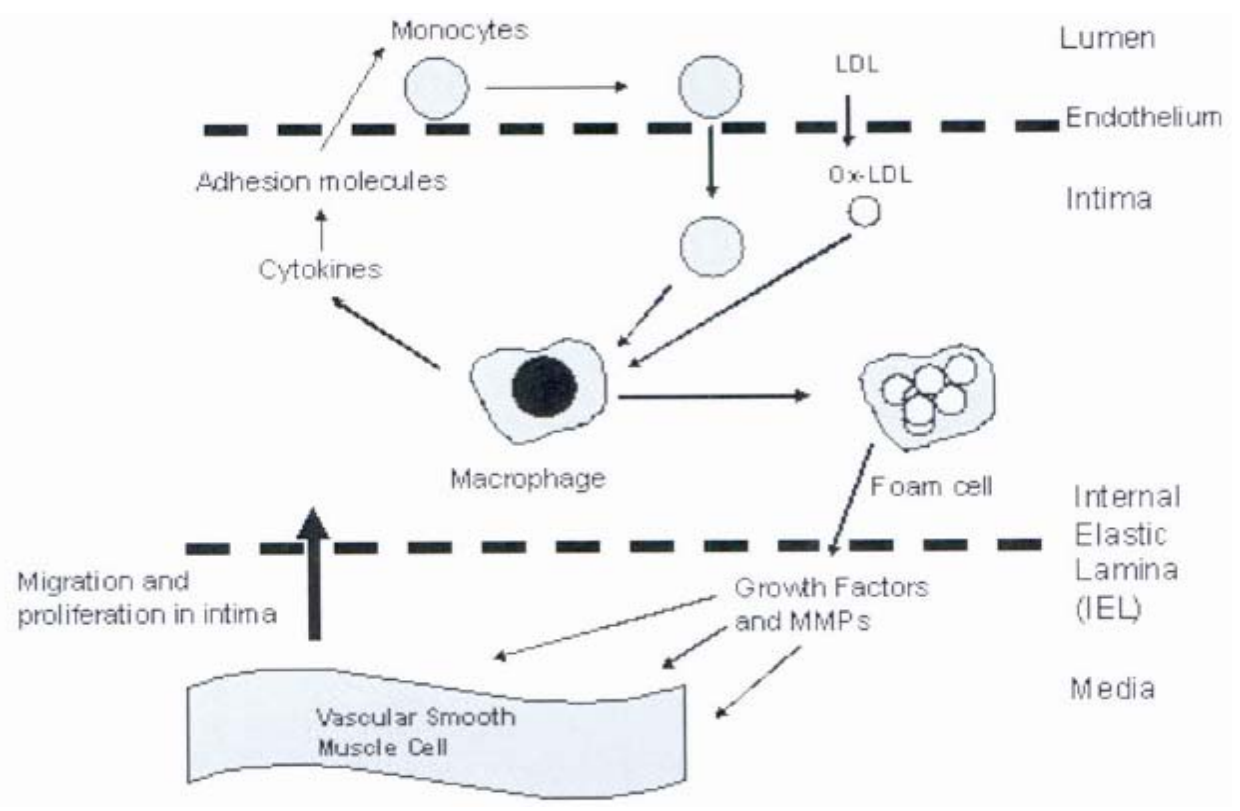

Gambar 1. Skema proses aterogenesis.?

\section{PERAN INTERLEUKIN-1 PADA ATEROSKLEROSIS}

Peningkatan kadar interlukin-1 (IL-1) di sirkulasi berhubungan dengan adanya faktor-faktor risiko penyakit kardiovaskuler seperti diabetes mellitus, hipertensi, merokok dan hiperlipidemia. Peningkatan kadar IL-1 mengakibatkan peningkatan sekresi kemokin dan sitokin lainnya seperti IL-6, peningkatan ekspresi molekul adhesi, mengaktivasi proliferasi endotel dan proliferasi sel otot polos, mengaktivasi makrofag dan meningkatkan permiabilitas vaskuler. Cascade ini dapat menyebabkan terjadinya aterosklerosis. ${ }^{8}$

Mekanisme penting lain IL-1 pada proses aterosklerosis adalah efeknya dalam menyebabkan disfungsi endotel. IL-1 menstimulasi pelepasan endotelin-1 yang merupakan suatu vasokonstriktor yang kuat. IL-1 juga menstimulasi inducible nitric oxide synthase (iNOS) yang menyebabkan peningkatan pembentukan ROS dan reactive 
nitrogen species (RNS) seperti nitrotyrosine yang selanjutnya akan menyebabkan stres oksidatif dan disfungsi endotel. ${ }^{8}$

Perkembangan aterosklerosis terdiri dari tiga tahap, mulai dari tahap inisiasi, tahap progresi dan tahap komplikasi. IL-1 mempunyai peran penting dalam ketiga tahap tersebut seperti terlihat pada Gambar 2. Aktivitas dan efek IL-1 pada setiap tahap aterosklerosis berbeda-beda tergantung pada masing-masing tahap yang terjadi. Semakin lanjut tahap aterosklerosis yang terjadi semakin besar peran dari IL-1. Pada tahap inisiasi IL-1 berperan dalam menyebabkan disfungsi endotel, selanjutnya pada tahap progresi selain menyebabkan disfungsi endotel IL-1 juga berperan dalam mengaktivasi lekosit dan protease. Kemudian pada tahap komplikasi IL-1 mengakibatkan aktivasi platelet sampai menyebabkan terjadinya ruptur plak ateroma dan selanjutnya mengakibatkan trombosis. ${ }^{9}$

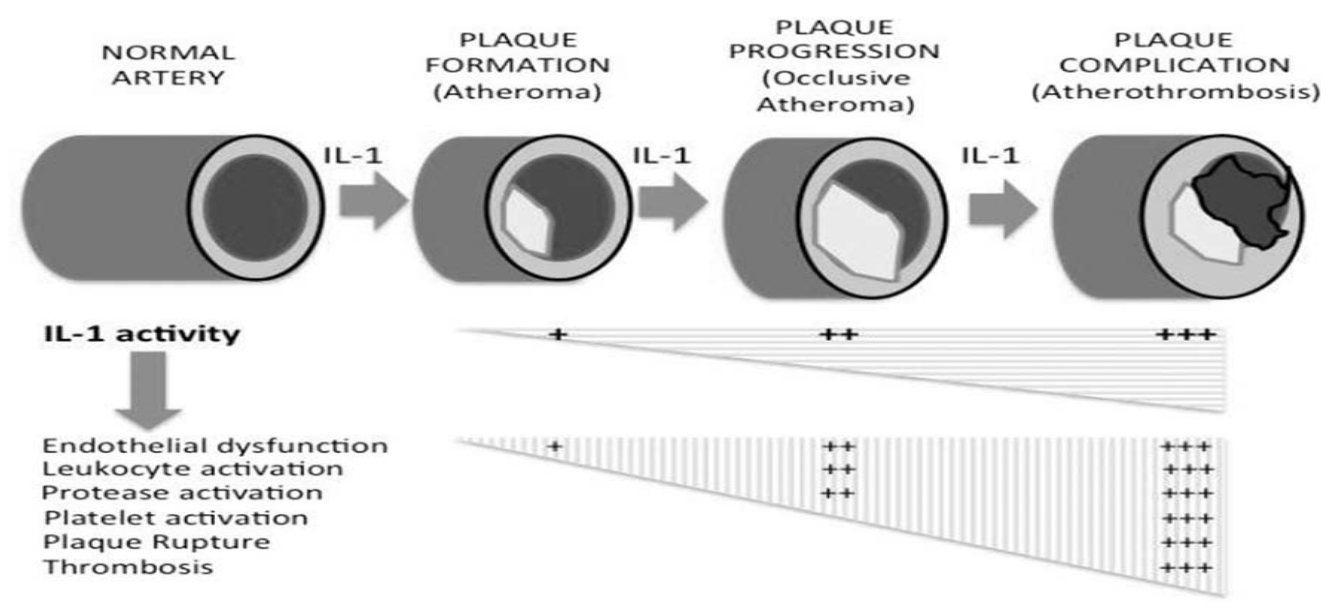

Gambar 2. Aktivitas IL-1 dalam setiap tahap aterosklerosis. ${ }^{9}$

Interleukin-1 dan IL-1 ra mempunyai peran penting dalam patogenesis aterosklerosis. Pengikatan IL-1 pada IL-1 type I receptor menghasilkan respon inflamasi yang berimplikasi pada perkembangan dan progresivitas dari disfungsi endotel, aterogenesis dan instabilitas dari plak ateroma. IL-1 ra secara kompetitif menghambat ikatan IL-1 dengan IL-1 type I receptor. ${ }^{8}$ IL-1ra merupakan anggota dari IL-1 family yang berikatan dengan reseptor IL-1 tanpa menginduksi respon seluler sehingga bersifat sebagai antagonis kompetitif terhadap efek inflamasi oleh ILlá dan IL-1 $\beta$. Aktivitas dari IL-1ra tergantung pada kadarnya. Ketidakseimbangan antara IL-1 dengan IL-1ra merupakan salah satu faktor yang dapat menyebabkan terjadinya berbagai macam penyakit termasuk aterosklerosis (Gambar 3). ${ }^{9}$
Penelitian preklinik membuktikan peran IL-1 pada perkembangan dan progresivitas dari aterosklerosis. Penelitian pada mencit dengan IL-1 knockout dan IL-1 type I receptor knockout menunjukkan adanya penghambatan pembentukan lesi aterosklerosis. Selanjutnya pada mencit yang mengalami defisiensi IL-1ra justru mengalami aterogenesis setelah mengalami kerusakan endotel. Penelitian lainnya menunjukkan pemberian IL-1 pada arteri koroner babi menyebabkan pembentukan neointima, sedangkan pemberian IL-1ra pada arteri koroner babi yang mengalami balloon-injured dapat menghambat pembentukan neointima. Penelitian klinis yang telah dilakukan menunjukkan terjadinya peningkatan konsentrasi IL- $1 \beta$ pada arteri koroner yang mengalami aterosklerosis. ${ }^{8,9}$ 


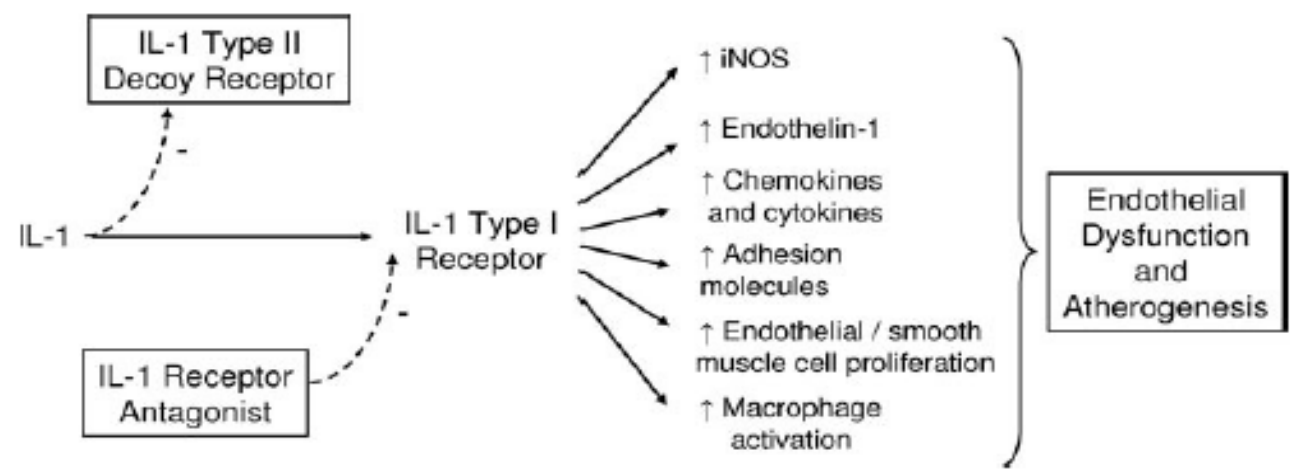

Gambar 3. Peran IL-1 dan IL-1ra pada aterosklerosis. ${ }^{8}$

Berdasarkan peran interleukin dalam patogenesis aterosklerosis, maka dapat dilakukan modifikasi interleukin sebagai strategi untuk mencegah terjadinya aterosklerosis. Strategi yang dapat dikembangkan antara lain melalui penghambatan ekspresi/translasi interleukin proaterogenik dan reseptornya, penghambatan interleukin/receptor processing, netralisasi interleukin proinflamasi, penggunaan antagonis reseptor interleukin, up-regulation dari interleukin antiinflamasi, penghambatan interleukin signaling dan penghambatan induksi ekspresi gen oleh sitokin. ${ }^{10}$ Diantara strategi tersebut penggunaan antagonis reseptor interleukin seperti IL-1ra mulai mndapat perhatian. Dalam beberapa tahun terakhir IL-1 ra mendapat perhatian karena perannya pada beberapa penyakit. Peningkatan kadar IL-1 ra dalam sirkulasi berhubungan dengan penghambatan respon terhadap IL-1 sehingga dapat mencegah terjadinya respon inflamasi yang berlebihan. ${ }^{9}$

\section{INTERLEUKIN 1 RECEPTOR ANTA- GONIST (ANAKINRA)}

\section{Struktur Anakinra}

Anakinra adalah suatu interleukin 1 receptor antagonist. Anakinra merupakan bentuk non glikosilasi dari human IL-1ra melalui teknik DNA rekombinan. Obat ini terdiri dari 153 asam amino dengan berat molekul 17,3 KD. Anakinra mempunyai bioavailabilitas $95 \%$ pada pemberian secara subkutan. Kadar puncak plasma dicapai dalam waktu 3-7 jam setelah pemberian subkutan, sedangkan waktu paruhnya adalah 4-6 jam. ${ }^{11}$

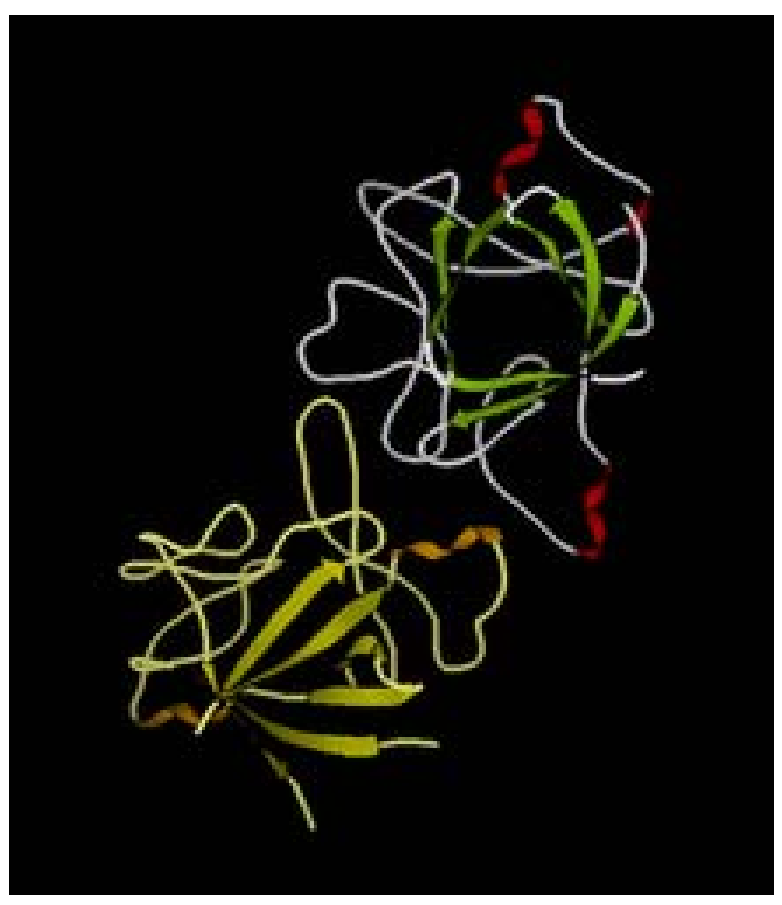

Gambar 4. Struktur molekuler anakinra. ${ }^{11}$

\section{Mekanisme Kerja}

Anakinra menghambat aktivitas IL-1 dengan menghambat secara kompetitif ikatan IL-1 pada reseptornya sehingga akan mencegah transduksi sinyal intrasel. ${ }^{9,11}$ Efek antiinflamasi yang dimiliki oleh anakinra terbukti bermanfaat untuk mengobati penyakit inflamasi. Efek antiinflamasi ini juga dapat dimanfaatkan untuk mengobati penyakit kardiovaskuler. Penelitian yang dilakukan pada pasien artritis rematoid yang mendapat anakinra menunjukkan perubahan signifikan pada biomarker 
proinflamasi yang berhubungan dengan perbaikan pada fungsi vaskuker. ${ }^{8}$ Namun masih diperlukan penelitian lebih lanjut untuk menilai efek terapi anakinra pada pasien yang mengalami aterosklerosis. Anakinra dan obat-obat lain yang bekerja dengan memengaruhi IL-1 dapat dilihat pada tabel berikut ini.

Tabel 1. Kerja anakinra dan obat-obat lain pada IL-1 family. ${ }^{9}$

\begin{tabular}{lccccc}
\hline & & & \multicolumn{3}{c}{ Blockade } \\
\cline { 4 - 6 } Name & Trade Name & Mechanism & IL-1 $\alpha$ & IL-1 $\beta$ & IL-1Ra \\
\hline Anakinra & Kineret & Receptor antagonist & $\mathrm{Y}$ & $\mathrm{Y}$ & $\mathrm{N}$ \\
Rinalocept & Arcalyst & $\mathrm{IL}-1$ trap & $\mathrm{Y}$ & $\mathrm{Y}$ & $\mathrm{Y}$ \\
Canakinumab & Ilaris & $\mathrm{IL}-1 \beta$ antibody & $\mathrm{N}$ & $\mathrm{Y}$ & $\mathrm{N}$ \\
Gevokizumab & $\ldots$ & $\mathrm{IL}-1 \beta$ antibody & $\mathrm{N}$ & $\mathrm{Y}$ & $\mathrm{N}$ \\
\hline
\end{tabular}

Secara skematik mekanisme kerja molekuler dari anakinra dan obat-obat lainnya dapat dilihat pada Gambar 5. Pada gambar tersebut terlihat anakinra bekerja sebagai antagonis pada reseptor IL-1 sehingga menghambat interaksi antara IL-1 $\beta$ dengan reseptornya yang akan menghambat timbulnya efek dari IL-1 $\beta$ tersebut. Sementara obat lain seperti canakinumab bekerja sebagai antibodi terhadap IL$1 \beta$ dan rilonacept bekerja dengan menangkap IL-1 sehingga tidak dapat berinteraksi dengan reseptornya. $^{9}$

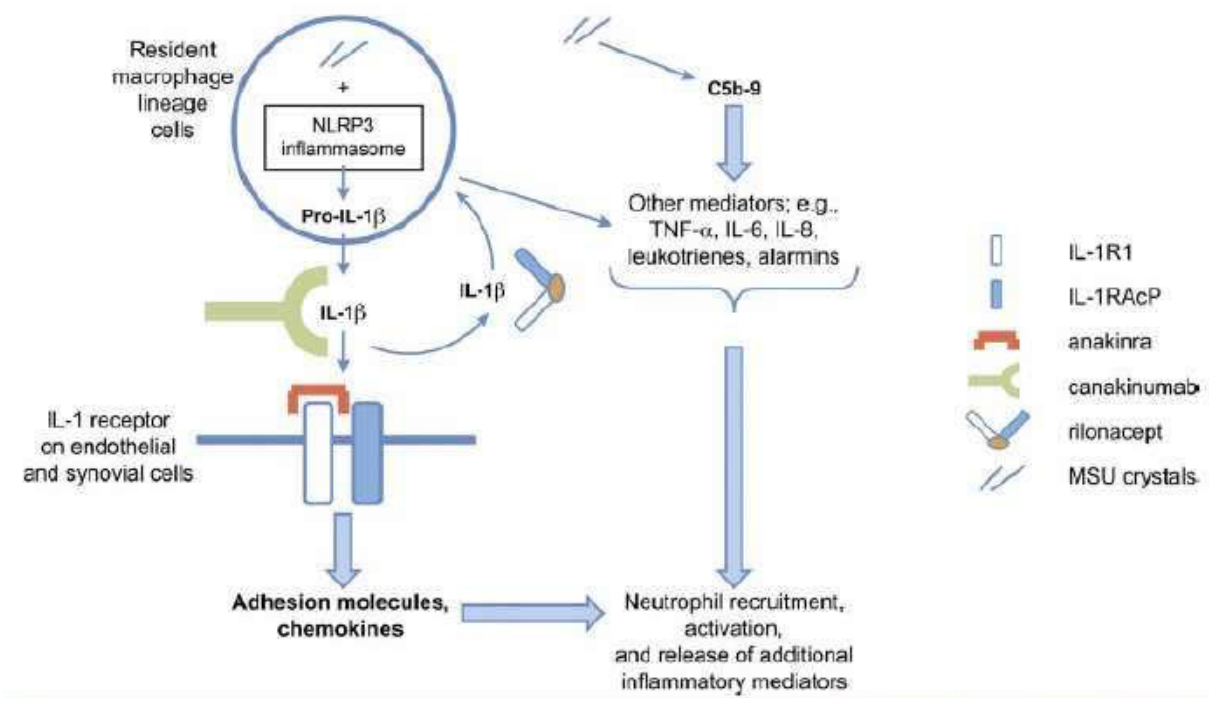

Gambar 5. Mekanisme kerja molekuler anakinra dan beberapa obat lainnya. ${ }^{9}$

\section{PENUTUP}

Inflamasi merupakan mekanisme utama yang mendasari patogenesis aterosklerosis. Berbagai bukti menunjukkan peran inflamasi dalam setiap tahap aterosklerosis mulai dari tahap inisiasi, progresi sampai tahap komplikasi. Salah satu mediator proinflamasi yang berperan adalah IL-1 $\beta$, penghambatan ikatan IL-1â pada reseptornya dapat mencegah transduksi sinyal intrasel sehingga pemberian antagonis reseptor IL-1 dapat mencegah terjadinya aterosklerosis.

\section{DAFTAR PUSTAKA}

1. Chen C, Khismatullin DB. Oxidized low-density lipoprotein contributes to atherogenesis via coactivation of macrophages and mast cells. Plos One $2015 ; 10: 3$. 
2. Li Y, Guo Y, Chen Y, Wang Y, You Y, Yang Q, et al. 2015. Establishment of an interleukin 1â induced inflammation activated endothelial cell smooth muscle cell mononuclear cell co culture model and evaluation of the anti inflammatory effects of tanshinone IIa on atherosclerosis. Molecular Medicine Reports 2015;12:1665-76.

3. Hansson GK, Libby P. The immune response in atherosclerosis: a double-edged sword. Immunology 2006;6:508-19.

4. Verma S, Gupta M, Ridker PM. Therapeutic targeting of inflammation in atherosclerosis: we are getting closer. Can J of Cardiol 2012;28:61922.

5. Libby P, Okamoto Y, Rocha VZ, Folco E. Inflammation in atherosclerosis: transition from theory to practice. Circulation 2010;74:213-20.

6. Hansson GK. Inflammation, atherosclerosis, and coronary artery disease. N Eng1 J Med 2005;352:1685-95.
7. Mitra AK, Del Core MG, Agrawal DK. Cells, cytokines and cellular immunity in the pathogenesis of fibroproliferative vasculopathies. Can J of Physiol and Pharmacol 2005;83:8-9.

8. Fearon, WF, Fearon DT. Inflammation and cardiovascular disease: role of the interleukin-1 receptor antagonist. Circulation 2008;117:25779.

9. Van Tassell BW, Toldo S, Mezzaroma E, Abbate A. Targeting interleukin-1 in heart disease. Circulation 2013;128:1910-23.

10. Von der Thusen JH, Kuiper J, Van Berkel TJC, Biessen EAL. Interleukins in atherosclerosis: molecular pathways and therapeutic potential. Pharmacol Rev 2003;55:133-66.

11. Sujatha MB. Anakinra-an overview. Kerala J of Orthopaed 2011;25:1. 